\title{
ROLE OF NUTRIENTS IN RICE (Oryza sativa L.): A REVIEW
}

\author{
Jiban Shrestha ${ }^{1^{*}}$, Manoj Kandel ${ }^{2}$, Subash Subedi ${ }^{3}$ and Kabita Kumari Shah ${ }^{4}$ \\ ${ }^{1}$ Nepal Agricultural Research Council (NARC), \\ Agriculture Botany Division, Khumaltar, Lalitpur, Nepal, \\ ${ }^{2}$ Hill Crops Research Program, NARC, Kabre, Dolakha, Nepal, \\ ${ }^{3}$ National Maize Research Program, NARC, Rampur, Chitwan, Nepal \\ ${ }^{4}$ Gokuleshwor Agriculture and Animal Science College (GAASC), \\ Tribhuvan University, Baitadi, Nepal \\ *Corresponding author : jibshrestha@gmail.com
}

Received : 10 April 2020 Accepted : 30 May 2020

\section{ABSTRACT}

Nutrients are important for plant growth and development. In this review, previous works were evaluated to investigate the role of nutrients, nutrient deficiency and toxicity in rice. Both macro and micronutrients are necessary for rice plants. Every nutrient has its own character and is involved in different metabolic processes of plant life. Nutrients affect the disease tolerance or resistance of plants to pathogens. Nutrient deficiency and toxicity conditions inhibit normal plant growth and exhibit characteristic symptoms. For optimal growth, development, and production, plants need all the necessary nutrients in balance. Integrated nutrient management in rice has many benefits to increase soil fertility and sustainable crop productivity. The information of this review article would be useful to rice growers and researchers for sustainable and higher rice production.

Keywords: Deficiency, Growth, Nutrient, Rice, Toxicity, Yield.

\section{INTRODUCTION}

Rice (Oryza sativa L.) is a staple food for more than half of the world's population. Its production worldwide is 510.6 million tons (FAO, 2018). Muthayya et al. (2014) observed rice produces up to $50 \%$ of the dietary caloric supply for millions of people living in poverty in Asia. It is an important food crop in Latin America and Africa. Nutrient management is an important part of the soil and plant management system. Knowledge of the nutrients required at all stages of growth and an understanding of the soil's ability to provide the necessary nutrients are crucial for profitable crop production. Sixteen nutrients are considered important for rice, where N, P and K are the primary macronutrients; $\mathrm{Mg}, \mathrm{Ca}$, and $\mathrm{S}$ are secondary macronutrients; and $\mathrm{Zn}, \mathrm{Fe}, \mathrm{Mn}, \mathrm{Cu}, \mathrm{B}, \mathrm{Mo}$ and $\mathrm{Cl}$ are micronutrients. Nitrogen $(\mathrm{N})$, phosphorus $(\mathrm{P})$, potassium (K) and sulfur (S) are the most important nutrients for plants. The subsequent factors influence Nitrogen in rice yield and consistency organ construction, physiological attributes, and component synthesis as well as their dissemination (Maathuis, 2009). Maathuis (2009) recorded P is active in cell membrane formation and multiple metabolic processes, and facilitates rice production and physiological metabolism. K, an intracellular control osmotic activator and membrane protein transfer, are active as an activator of different enzymes. Consequently, in carbohydrate transport in rice, $\mathrm{K}$ is also absolutely vital and essential for plant metabolism as well as resistance to stress (Wang and $\mathrm{Wu}, 2013$; Nieves-Cordones et al., 2019). Throughout the early to mid-tillage phase, nitrogen is most commonly needed for the Initiation of panicles, grain development, and booting stages. Dobermann and Fairhust (2000) observed the application of the nitrogen fertilizer will 
maximize rice yield ability by steadily increasing plant height, spikelet count, panicles numbers as well as the number of filled spikelets. In facilitating the early flowering and maturity stage, phosphorus plays a significant role in sustaining the root growth mechanism as well as the resistance to disease and drought tolerance. Deficient phosphorus will extend the maturity (Fageria, 1980) of the rice plant and render rice disease more susceptible (Fageria et al., 2003). Kong et al. (2014) demonstrated the effective application of potassium is strongly correlated with lignification of sclerenchyma cell, vascular bundles and strong resistance to lodging. Application of Si can control rice diseases as similar obtained by using fungicide applications. Similary $\mathrm{Mn}$ application controls a number of rice diseases. B reduces the severity of many diseases and $\mathrm{Cl}$ application can enhance host plants' resistance to disease.

The critical stages of rice are emergence, tillering, panicle Initiation, booting, heading and maturation. These stages are more sensetive and crop should be saved from stress of nutrition. The lack of some micro and secondary nutrients is one of the main causes of stagnation in crop productivity. Rice shows marked symptoms of nutrient deficiency of nitrogen $(\mathrm{N})$, phosphorus $(\mathrm{P})$ and potassium $(\mathrm{K})$ and these symptoms form the basis for rapid morphological diagnoses in the field. NPK-deficient rice often has a large number of symptoms. In the absence of $\mathrm{N}$, all the leaves become light green and chlorotic at the tips. With the exception of younger and greener leaves, the leaves are narrow, short, errect and lemon yellow. During $\mathrm{P}$ deficiency, the leaves are narrow, short, very errect. During K deficiency, dark green plants with yellowbrown leaf margins or dark brown necrotic spots first appear at the tips of old leaves. With a strong $\mathrm{K}$ deficiency, the leaf tips become yellowish brown. Old leaves vary from yellow to brown (Armstrong, 2002; Chen et al., 2014). Zinc deficiency (Zn) is a common occurrence that limits productivity in lowlands. Manganese deficiency (Mn) is more common in he upland rice, alkaline and calcareous soils with a low status of organic matter. Iron (Fe) deficiency is generally observed in rain-fed upland ric. It distinguishes between visual symptoms, especially the observed and varying symptoms of disease symptoms (Nayak et al., 2013), severe deficiency (in some cases hidden hunger), and toxicity. Rice plant potassium deficiencies are usually correlated with elevated rates of disease infections which can even correspond to lodging. Zn deficiency, Fe deficiency and $B$ toxicity in rice in the wetland and the Fe deficiency, B deficiency, and Mn toxicity in rice in the upland are amongst the most widespread micronutrient disorders in rice. Through the application of the element in the soil or the plant, nutrient deficiencies may be resolved. A balanced application of fertilizers increases the efficiency of fertilizer use and increases the physical, chemical and biological environment of the soil, which leads to an increase in crop yield. In this review, we highlighted important results of published research articles regarding to role of nutrients, nutrient deficiency and toxicity in rice growth, development and production. This information would be useful for rice farmers and researchers.

\section{Nutrients and their roles in rice}

\section{Nitrogen}

Soil organic matter offers significant amounts of nitrogen which are essential for the growth and optimum yield of rice and are a primary component of amino acid and protein building blocks, nucleic acids and chlorophyll. $\mathrm{N}$ fertilization increased disease severity. The deficiency symptoms, because of the mobile behavior of nitrogen in plants, are first seen on old and then younger seeds, and eventually chlorotic and dead if the insufficiency concentration has been reached to the maximum. The volume of nitrogen used represented the ascribing characteristics for yield and yield other than tiller number, spikelets number, panicle length, plant height and length in rice (Dobermann and Fairhust, 2000). Leaching, volatilization, denitrification, etc. of nitrogen may be a loss to the soil and effective management is therefore mandatory for maximum output and successful use under different conditions of cultivation, such as lowland, upland, etc. In the anaerobic environment of 
lowland rice fields, the stable mineral form of $\mathrm{N}$ is $\mathrm{NH}_{4}$ + , which is to be applied to fields. When used in low land fields, the nitrate form $\left(\mathrm{NO}_{3}^{-}\right) \mathrm{N}$ enters the anaerobic zone and causes severe loss of denitrification. At planting time, the base-dressing of $\mathrm{N}$ should never be supplied as nitrate. For topdressing the growing plants, however, $\mathrm{NH}_{4}+$ and $\mathrm{NO}_{3}$ - forms may be used with almost equal efficiency. Fully established rice can rapidly take up applied $\mathrm{NO}_{3}-$

\section{Phosphorous}

Several significant phosphorous interventions in plants involve the development of the energy parameter genetic materials and adenosine triphosphate through the synthesis of nucleotides, glycophosphate, and phospholipids. The drastic decline in development and yield is related to seed deficiency. Phosphorus is responsible for the development of root, ripening, early flowering and tolerance to specific biotic and abiotic stresses in rice. Its deficiency will contribute to maturity delays and rice vulnerability to diseases increased (Fageria et al., 2003). At the time of the tillering process, rice began accumulating dry matter and deficiency in phosphorus appeared as stunting, erecting dark green leaves (Marschner 1995). The deficiency of phosphorus may result in rice maturity being delayed by a week or two (Fageria, 1980). The nutritional absorption of Phosphorus by rice relies on the soil's potential and desorption and deficiency characteristics, no and little reaction to major and minor nutrients including, potash, nitrogen, and zinc via rice in the soil (Roy and De Datta, 1985). In soil solutions, rice plants rarely consume more than $20 \%$ of overall fertilizer Phosphorous and availability of $\mathrm{P}$ in soil solution dictates their soil's capacity to retain inorganic $p$ in soil solution (Friesen et al., 1997). Sanyal and De Datta (1991) demonstrated that, under alternative anaerobic-aerobic environments, Phosphorus ability for soil absorption and bonding energy of Phosphorous enhanced.

\section{Potassium}

Potassium is an essential factor in optimizing root development, enhancing plant vigor, reducing lodging, encouraging cell division, supplying osmotic pull, helping to neutralize organic acid, and boosting seed resistance to pests and diseases, helps in maintaining metabolism. $\mathrm{K}+$ and one of the key restricting nutrients after nitrogen are present in rice. It is especially essential to monitor levels under waterlogged conditions in the lignifications of vascular bundles. The acceptable application of potassium is closely allied with sclerenchyma cells lignification and vascular bundles and clum that enhance lodging resistance (Kong et al., 2014). Characteristic deficit signs of $\mathrm{K}$ in rice are interveinal chlorosis and margins of the bottom leaf beginning at the tip of the leaf, which is reminiscent of $\mathrm{N}$-deficiency, but minimal or no reduced tillering, stunted appearance and upper dark green leaves (Fageria et al., 2003). K signs of deficiency in the rice leaf may be ambiguous with the disease of tungro, but tungro appears in field areas and typically has more defined orange and yellow leaves with stunting appearance. The deficiency of potassium contributes to a direct loss of yield owing to decreased rice grain size and weight.

Zinc

Quijano-Guerta et al. (2002) reported that zinc is an integral rice micronutrient accessible in the form of $\mathrm{Zn++}, \mathrm{ZnCl}+, \mathrm{ZnO}_{2}$, and so on, which occurs in the nursery as well as after transplants and has prevalent productivity restricting phenomena under lowland conditions. Zinc is the cofactor for enzymes that are active in $\mathrm{N}$ metabolisms such as alcohol dehydrogenase and glutamate dehydrogenase. Zn deficiency significantly reduces the alcohol dehydrogenase function, declines anaerobic root metabolism and lessens rice seedlings capacity to cope with anaerobic soil conditions (Moore and Patrick, 1988). Rice plants are more susceptible to Zn deficiency in early growth phases. In the reproductive growth period, if the deficiency is not addressed, this can also impact crops. As $\mathrm{Zn}$ is not quite mobile inside the plant, its signs of deficiency first become chlorotic on the base of the leaf during the early stages of $\mathrm{Zn}$ deficiency in the youngest plants. Yoshida (1981) reported when the Zn deficiency continues to progress, the midribs, as well as the base of 
older leaves, can also turn yellow or light green with brown blotches and streaks. The deficit of $\mathrm{Zn}$ becomes more serious if the large levels of $\mathrm{N}$ and $\mathrm{P}$ are used, according to Mueller (1974). The use of a significant rate of $\mathrm{P}$ fertilizer will aggravate Zn's deficiency by $\mathrm{Zn}$ phosphate formation in soil solvent and/or the excessive impact inhibiting $\mathrm{P}$ metabolization in the plant Zn. Fageria (2001) reported that Rice is deemed prone to $\mathrm{Zn}$ deficiency as $\mathrm{Zn}$ rates are not sufficient in soil limits tillering, and therefore the number of panicles/region.

\section{Iron}

Iron $(\mathrm{Fe})$ plays a vital function in rice photosynthesis. It may impede $\mathrm{K}$ absorption because of its deficiency. The youngest rice leaves show the very first symptoms of its deficiency because of their immobile nature. The initiation of Fe deficiency is identified with interveinal yellowing and chlorosis of developing plants. The advancement of Fe deficiency contributes to a standardized pale yellow appearance with bleached appearances (Snyder and Jones, 1988).

\section{Boron}

Boron (B), a part of a cell wall, contributes to minimal pollen viability because of its deficiency. While deficiency symptoms typically occur well into the white rolled leaf tips of young plants when B is not retranslocated towards new growth. Boron deficit in rice can only be depicted in the form of lower grain yield from "oret sterility". Okuda et al. (1961) observed Bdeficient rice plant panicles certainly did not allow them to come out of the boot and eventually decreased grain production.

Table 1. Nutrients and their functions in rice

\begin{tabular}{ll}
\hline Nutrients & Functions \\
\hline Nitrogen $(\mathrm{N})$ & $\begin{array}{l}\text { It increases height of plant and tillers' number. It plays an important role in the synthesis of } \\
\text { enzymes proteins, hormones, nucleic acids (DNA, RNA), alkaloids, vitamins etc. }\end{array}$ \\
\hline Phosphorus (P) & $\begin{array}{l}\text { It plays an important role in protein metabolism and energy transfer. It is mportant part of } \\
\text { nucleotides, sugar phosphates, co-enzymes, nucleic acids, and phospholipids. }\end{array}$ \\
\hline Potassium(K) & $\begin{array}{l}\text { It facilitates osmotic and ionic control and requires more than } 40 \text { enzymes as cofactors or } \\
\text { activators. It gives resistance to diseases and drought. }\end{array}$ \\
\hline Sulfur (S) & $\begin{array}{l}\text { It plays a key role in cellular energy. It plays an important role in the synthesis of amino acids } \\
\text { and lipids. }\end{array}$ \\
\hline Calcium(Ca) & $\begin{array}{l}\text { It plays an important role in maintaining cell division and membrane integrity. Calcium is an } \\
\text { integral part of the cell wall in the form of pectate. }\end{array}$ \\
\hline Magnesium $(\mathrm{Mg})$ & $\begin{array}{l}\text { It is an integral part of ribosomes. This is the central part of the chlorophyll. Mg is necessary } \\
\text { for some enzymes involved in phosphate transfer. }\end{array}$ \\
\hline Zinc $(\mathrm{Zn})$ & $\begin{array}{l}\text { It is an important component of various enzyme systems (such as dehydrogenase, protease, } \\
\text { peptidase, carbon dioxide and alcohol dehydrogenase). }\end{array}$ \\
\hline Iron (Fe) & $\begin{array}{l}\text { It plays an important role as a catalyst in plants, which are part of various enzymes } \\
\text { (cytochromes, catalases, dipeptides, etc.). It is a major component of various redox reactions } \\
\text { of photosynthesis and respiration. }\end{array}$ \\
\hline Manganese $(\mathrm{Mn})$ & $\begin{array}{l}\text { It plays an important role in the production of } \mathrm{O}_{2} \text { in the process of photosynthesis and is } \\
\text { important component of decarboxylase, kinase and oxidase. This component is necessary for } \\
\text { respiration, nitrate reduction and chlorophyll formation. }\end{array}$ \\
\hline Molybdenum $(\mathrm{Mo})$ & $\begin{array}{l}\text { It is used to reduce nitrate to nitrite. Nitrogen is an integral part of a small amount of nitrate } \\
\text { reductase, and xanthane hydrogen enzyme and sulfate oxidase, }\end{array}$ \\
\hline $\begin{array}{l}\text { Because it acts as a component of metalloenzymes. In regulation of enzyme activity and } \\
\text { acceleration of oxidative reactions, Cu plays a role in: (i) the exchange of nitrogen, proteins } \\
\text { and hormones; i) respiration and photosynthesis. }\end{array}$ \\
\hline
\end{tabular}




\begin{tabular}{ll}
\hline Chlorine $(\mathrm{Cl})$ & $\begin{array}{l}\text { It is required for photosynthesis and acts as enzyme activators that plays a role in water } \\
\text { degradation due to osmosis of plants growing in saline soils. }\end{array}$ \\
\hline Boron $(\mathrm{B})$ & $\begin{array}{l}\text { This is necessary for the growth and development of new plant meristem cells. . It is necessary } \\
\text { for the formation of flowers, germination of pollen, and for the absorption of cations }\end{array}$ \\
\hline
\end{tabular}

(Source: Agrinfobank, 2019).

Table 2. Nutrient Interaction and Plant Nutrition

\begin{tabular}{ll}
\hline SN & Nutrient Interaction \\
\hline 1 & The low levels of N, S and Mg showed high absorption of Mn and low uptake of Fe. \\
2 & Zn deficiency is induced by P \\
3 & Application of K reduces Mn and Fe levels in a rice plant \\
4 & Increasing the pH value by applying lime reduces the availability of Zn for plants. \\
5 & Zn application inhibits extractable Fe, but increases Mn in submerged rice soils \\
6 & Use of Cu reduce Fe and Mn in submerged rice soils \\
7 & A high iron content in the soil inhibits the absorption of copper \\
8 & Mn inhibits Zn absorption by the rice root, but favor Zn translocation in plants. Mn inhibits iron movement \\
9 & From root to shoot \\
10 & Zinc deficiency occurs in normal and saline-sodic soils \\
11 & Iron toxicity occurs in acidic soils
\end{tabular}

(Source: Das, 2014).

\section{Nutrient uptake of rice}

Interactions between plant nutrients can produce antagonistic or synergistic results that affect the efficiency of nutrient use. The uptake of the nutrients depend on the interactions of the individual nutrient. A nutrient can reduce the absorption of another nutrient known as antagonism. On the other hand, uptake can be mutually enhanced - this interaction is called synergism (Farago, 1994). Antagonistic and synergistic interactions can occur between macro and micro nutrients, some micro nutrients can influence the uptake of macro nutrients, and vice versa.

Table 3. Antagonistic interaction of nutrients

\begin{tabular}{lll}
\hline SN & Excess element & Nutrients affected \\
\hline 1 & Nitrogen & Potassium, calcium \\
2 & Potassium & Nirogen, magnesium, calcium \\
3 & Phosphorus & Zinc, iron, copper \\
4 & Iron & Manganese \\
5 & Magnesium & Calcium, potassium \\
6 & Sodium & Potassium, calcium, magnesium \\
7 & Copper & Molybdenum, iron, manganese, zinc \\
8 & Calcium & Boron, phosphorus, magnesium, \\
9 & Molybdenum & Copper, iron \\
10 & Zinc & Iron, manganese \\
11 & Sulfur & Molybdenum, manganese, iron,, zinc \\
\hline
\end{tabular}

(Source: Rietra et al, 2015; Rx Green Technologies, 2020) 
The role of nutrient absorption, especially nitrogen $(\mathrm{N})$, phosphorus $(\mathrm{P})$ and potassium $(\mathrm{K})$, in the root system is primarily influenced by rice growth and development. The inorganic nitrogen consumption was higher than that of organic or integrated organic and inorganic sources of $\mathrm{N}$ on sandy clay loam soils with 120 $\mathrm{kg} \mathrm{N} /$ ha (Prasad, 1994). Radha Madhav et al. (1996) reported urea applications indicated that positive results on the absorption of NPK were seen throughout the early stages of crop development, with implications in later phases of organic sources (FYM, gliricidia, eichornea, ipomoea). In the tillering phase, Khan et. al. (1986) documented $\mathrm{N}$ absorption was higher when the application of the urea and FYM was integrated than when urea was alone administered. Phosphorus absorption by rice has been optimum because of poultry manure @ 5 t/ha and minimal when single super phosphates have been added at $21.8 \mathrm{~kg} \mathrm{p} / \mathrm{ha}$ (Datta and Banik, 1994). Nonetheless, Gupta et al. (1995) reported the maximum $P$ intake by rice with integrated usage of inorganic $\mathrm{P}$ and poultry manure. In addition to the prescribed fertilizer dosage, the usage of FYM @ $5 \mathrm{t} / \mathrm{ha}$ contributed to considerably improved intakes of N, P and $\mathrm{K}$ by rice (Rabeya Khanam et al., 1997). Khan et al. (1986) has demonstrated that, in the first stages of rice production, there was sufficient availability of $\mathrm{N}$ for soil and contented $\mathrm{n}$ specifications for rice crop in the form of a combination $30 \mathrm{~kg} \mathrm{~N} /$ ha for planting puddling and $30 \mathrm{~kg} \mathrm{~N} /$ ha for the cultivation of urea. Corporation of 25:75 FYM proportion straight fertilizing was reported as the highest P-uptake, whereas the combination of 25:75 vermicompost and straight fertilizer displayed substantial improvement in K uptake (Jadhav et al., 1997). Researchers also found that $P$ and $K$ soil level in sesbania, poultry manure @ $5 \mathrm{t} / \mathrm{ha}$, pongamia plots were higher. Increased $\mathrm{N}$ and $\mathrm{P}$ availability were demonstrated with the continuous integrated introduction of FYM and NPK fertilizers, and a combination of compost and the $\mathrm{K}$ fertilizer reported greater soil $\mathrm{K}$ levels available (Udayasoorian and Paramasivam, 1991). Selvi and Ramaswami (1995) have reported that the accessible $\mathrm{N}, \mathrm{P}$, and K contents of soil have been significantly enhanced by a rice-rice-pulse pattern impact of NPK and about organics in particular FYM. Singh and Meelum (1995) discovered that the amount of fertilizer $\mathrm{N}$ in rice varied between 42 and $52 \%$ of overall $\mathrm{N}$ added and the evident $\mathrm{N}$ recovery was $20 \%$ compared to FYM, associated with urea between 35 and $46 \%$. In comparison, the $\mathrm{N}$ mineralization in soil with a smaller C-N ratio in poultry manure. In the same way, FYM and compost usage @ 25 t/ha enhanced soil K quality accessible (Udayasoorian et al., 1989).

\section{Nutrient deficiency}

Rice deficiency of nitrogen is generally seen in rice fields because of its various depletion mechanisms. In nature, it's mobile. In the older leaf, they are short, narrow, erect and at the tip, they become lemon yellowish, chlorotic and greener to young leaf. The demand for $\mathrm{N}$ is greater than that and extreme case entire field appears as yellowish in two critical points, for instance tillering and panic initiation. The Potassium deficit tends to be narrow, short, strongly erect and dark 'dirty' green as in the older leaves. Stems are spindly and thin, and the development of plants is delayed. The panicle will, therefore, decrease the number of leaves, panicles, and grains. If the variety continues to contain anthocyanine the older leaf appears red and purple. If $\mathrm{N}$ and $\mathrm{P}$ deficiency arise at almost the same time, the leaves appear pale green while young leaves are normal. The first factor that occurs in the older leaves is a potassium deficiency because $\mathrm{K}$ becomes very mobile and is transferred from the older leaf to senescing leaves. Sometimes only when other nutrients, particularly $\mathrm{N}$ and $\mathrm{P}$, are given adequately are the yield response to $\mathrm{K}$ fertilizer observed. Dark green plants appear first on the tips of older leaves, with yellowishbrown leaf margins, or dark brown necrotic spots. This is also recognized as the energy currency of a plant because of its role in the system. Symptoms of potassium deficiency appear to emerge first on older leaves because $\mathrm{K}$ is very mobile inside the plant and continues to move from old senescent leaves to new leaves. Symptoms first emerge on the old leaves then on the leaf edge and then on the base of the leaf. Upper leaves are dark green, short, droopy and "dirty." Older leaves transition from brown to yellow and 
decoloration slowly occur on younger leaves where the deficiency is not addressed. The $\mathrm{K}$ deficiency leaf symptoms are identical to the tungro virus disease. This increases the resistance of rice plants for unfavorable weather conditions, insect pests, diseases, and lodging. It is also recognized as a chemical policeman. Symptoms of zinc deficiency are more common in young or middle-aged leaves. Dusty brown spots appear on the upper leaves of stunted plants, sometimes two to four weeks after transplantation, with irregular plant growth and pathched of poorly established hills. If there is a serious deficiency, tillering are reduced and the ripening period can be extended.

Table 4. Deficiency and toxicity of essential plant nutrients along with critical level content at different growth stages of rice plant

\begin{tabular}{l|l|l|l|l}
\hline Nutrients & $\begin{array}{l}\text { Deficiency } \\
(\mathrm{D}) / \text { toxicity }(\mathrm{T})\end{array}$ & $\begin{array}{l}\text { Critical level } \\
(\%)\end{array}$ & Growth stage & Plant part \\
\hline $\mathrm{N}$ & $\mathrm{D}$ & 2.50 & Tillering & Leaf blade \\
\hline \multirow{3}{*}{$\mathrm{P}$} & $\mathrm{D}$ & 0.10 & Maturity & Straw \\
\cline { 2 - 5 } & $\mathrm{T}$ & 1.00 & Maturity & Straw \\
\hline \multirow{2}{*}{$\mathrm{K}$} & $\mathrm{D}$ & 1.00 & Maturity & Straw \\
\cline { 2 - 5 } & $\mathrm{D}$ & 1.00 & Tillering & Leaf blade \\
\hline $\mathrm{Ca}$ & $\mathrm{D}$ & 0.15 & Maturity & Straw \\
\hline \multirow{2}{*}{$\mathrm{Sg}$} & $\mathrm{D}$ & 0.10 & Maturity & Straw \\
\hline \multirow{3}{*}{$\mathrm{Zn}$} & $\mathrm{D}$ & 0.10 & Maturity & Straw \\
\hline \multirow{2}{*}{$\mathrm{Mn}$} & & ppm & & \\
\hline \multirow{2}{*}{$\mathrm{Fe}$} & $\mathrm{D}$ & 20 & Tillering & Shoot \\
\cline { 2 - 5 } & $\mathrm{T}$ & 1500 & Maturity & Straw \\
\hline \multirow{2}{*}{$\mathrm{Cu}$} & $\mathrm{D}$ & 20 & Tillering & Shoot \\
\cline { 2 - 5 } & $\mathrm{T}$ & 2500 & Tillering & Shoot \\
\hline \multirow{2}{*}{$\mathrm{B}$} & $\mathrm{D}$ & 70 & Tillering & Leaf blade \\
\cline { 2 - 5 } & $\mathrm{T}$ & 300 & Tillering & Leaf blade \\
\cline { 2 - 5 } & $\mathrm{D}$ & 6 & Maturity & Straw \\
\cline { 2 - 5 } & $\mathrm{T}$ & 30 & Maturity & Straw \\
\cline { 2 - 5 } & $\mathrm{D}$ & 3.4 & Maturity & Straw \\
\hline
\end{tabular}

(Source: Tahir et al., 2019).

\section{Nutrient toxicity}

Rice fields with more Nitrogen application than their usual amounts may render the plant excessively green; they may be healthy, but they can also be lodged in the maturity stage (particularly in direct seed rice); they may have thinner stems and enhanced diseases (e.g. blight, sheath blight, bacterial leaf, blast) or insects (leaves folds); resulting patchy appearance when used unequal along the field. Rice field containing iron toxicity has insignificant brown spots on the bottom leaves, beginning from the tips and extends to the base; intravenous spots normally coincide with the leaves becoming burnt-orange and dying leaves typically persist narrow and sometimes green, as well as the overall leaf appears purplish-brown in extreme cases; dark brown coated to black on root cover and often dead roots; freshly uprooted, black roots are found in rice hills. Interveinal orange/yellow chlorosis on leaves that in extreme cases may turn necrotic; weak stunting; interveinal yellow/white mottling accompanied by the death of leaf tip and leaf margin scorch; under aluminum toxicity conditions, the stunted as well as deformed roots are observed in responsive cultivars in a rice field. More prevalent in the alkaline soil was the 
manganese toxicity of stunted plants and reduced tillering; brown spots on the leaf blade veins and sheaths, particularly the bottom blades. Chlorosis is particularly prominent at the tip of the older leaves on the margin, and broad dark-brown patches in the concerning areas are prevalent and subsequently become brown and dry; necrotic spots become conspicuous as the panicle initiation. Under the boron toxicity of rice plant soil, vegetative development is not greatly suppressed. On the upper leaf of stunted crops, which often occur from the next 2 to 4 weeks, with inappropriate crop growth and patches of improperly developed high hills, the dusty brown spots emerge under conditions of zinc toxicity in the rice region. Tillering declines and time to develop may also be increased under extreme deficiencies condition.

\section{Integrated nutrient management}

Integrated Nutrient Management (INM) aims to maintain or improve soil fertility by using balanced fertilizer with organic and biological resources from plants. The widespread use of INM can be a very important factor for sustainable agricultural production. INM helps in the efficient use of synthetic fertilizers that are integrated into organic sources of nutrients (Mahajan et al., 2008). Both chemical and

\section{REFERENCES}

Agrinfobank (2019) Micronutrients and Macronutrients in Rice Production. https://agrinfobank.com.pk/ micronutrients-and-macronutrients-in-rice-production/ Armstrong DL (2002) Nutrient Deficiency Symptoms in Rice. Better Crops International 16, Special Supplement: 23-25.

Bezbaruha R, Sharma RC and Banik P (2011) Effect of Nutrient Management and Planting Geometry on Productivity of Hybrid Rice (Oryza sativa L.) Cultivars. American Journal of Plant Sciences 2 (3): 297-302.

Chen L, Lin L, Cai G, Sun Y, Huang T, Wang, K and Deng J (2014) Identification of Nitrogen, Phosphorus, and Potassium Deficiencies in Rice Based onStatic Scanning Technology and Hierarchical Identification Method. PLoS ONE 9(11): e113200.doi:10.1371/journal. pone.0113200

Das S (2014) Role of Micronutrient in Rice Cultivation and Management Strategy in Organic Agriculture-A Reappraisal. Agricultural Sciences 5: 765-769. organic fertilizers should be used to improve physical, chemical and biological properties of soil. The integrated use of manure and inorganic fertilizer significantly influenced the yield and yield attributing characters of rice. Integrated nutrient management significantly improved rice yields by minimizing the loss of nutrients in the environment and managing the nutrient supply, and thereby results in high nutrient use efficiency (Kumar and Yadav, 2008; Bezbaruha et al., 2011; Parkinson, 2013).

\section{CONCLUSION}

The growth, development, and production of rice depends on the availability of nutrients in the soil. Understanding each nutrient's role in the plant can help to determine which nutrient is responsible for a deficiency or toxicity symptoms. Nutrient deficiency symptoms shown by rice throughout the growth period serve as an important diagnostic tool for plan nutrient management. Farmers can be benefited from the use of an integrated nutrient management approach through increased productivity and profitability.

\section{Conflict of Interest}

The authors declared that they have no conflicts of interest.

Datta M and Banik S (1994) Effect of poultry manure and phosphate dissolving bacteria on rice (Oryza sativa L.) in acid soil. Indian Journal of Agricultural Sciences 64(1): 791-793.

Dobermann A and Fairhurst T (2000) Rice: Nutrient Disorders and Nutrient Management. Handbook series. Potash and Phosphate Institute (PPI), Potash and Phosphate Institute of Canada (PPIC) and International Rice Research Institute. 191

Fageria NK (1980) Influence of phosphorus application on growth, yield and nutrient uptake by irrigated rice. Revista Brasileira de Ciência do Solo 4:26-31

Fageria NK (2001) Screening method of lowland rice genotypes for zinc uptake efficiency. Scientia Agricola 58:623-626

Fageria NK, Slaton NA and Baligar VC (2003) Nutrient management for improving lowland rice productivity and sustainability. Advances in Agronomy 80:63-152 Farago ME (1994) Plants and the chemical elements. Biochemistry, uptake, tolerance and toxicity. 
Weinheim, $\mathrm{VCH}$

FAO (2018) Rice market monitor. http://www.fao.org/3/I9243EN/i9243en.pdf

Friesen DK, Rao IM, Thomas RJ, Oberson A and Sanz JI (1997) Phosphorus acquisition and cycling in crop and pasture systems in low fertility tropical soils. In: Ando T, Fujita K, Mae T, Matsumoto H, Mori S, Sekiya J (eds) Plant nutrition for sustainable food production and environment. Kluwer Academic Publishers, Dordrecht, pp. 493-498

Gupta AP, Neve HU and Singh VP (1995) Increasing rice productivity through phosphatic fertilizer and poultry manure application in acid upland. Annals of Biology 11(2): 151-157.

Jadhav AD, Talashilkar SC and Powar AG (1997) Influence of the conjunctive use of FYM, vermicompost and urea on growth and nutrient uptake in rice. Journal of Maharastra Agriculture University 22(2): 249-250.

Khan SK, Mohanty SK and Chalam AB (1986) Integrated Management of organic manure and fertilizer nitrogen for rice. Journal of Indian Society of Soil Science 24:505-509.

Kong L, Sun M, Wang F, Liu J, Feng B, Si J, Zhang B, Li S and Li H (2014) Effects of High NH4+ on K+ Uptake, Culm Mechanical Strength and Grain Filling in Wheat. Frontier in Plant Science 5(703). doi: 10.3389/fpls. 2014.00703.

Kumar J and Yadav MP (2008) Effect of Integrated Nutrient Management on Growth, Yield Attributes, Yield and Economics of Hybrid Rice (Oryza sativa L.).Research on Crops 9:10-3.

Maathuis FJ (2009) Physiological functions of mineral macronutrients. Curr. Opin. Plant Biol. 12: 250-258.

Mahajan A, Bhagat RM, Gupta RD (2008) Integrated nutrient management in sustainable rice-wheat cropping system for food security in India. SAARC J. Agric. 6:1-13.

Marschner H (1995) Mineral nutrition of higher plants, $2^{\text {nd }}$ edn. Academic Press, New York

Moore PA Jr and Patrick WH Jr (1988) Effect of zinc de\#ciency on alcohol dehydrogenase activity and nutrient uptake in rice. Agronomy Journal 80: 882-885 Muthayya S, Rah JH, Sugimoto JD,Roos FF, Kraemer K and Black RE (2013) The Global 42 Hidden Hunger Indices and Maps: An Advocacy Tool for Action. PLoS One, 128(6):e67860. doi:10.1371/journal.pone.0067860. Nayak AK, Mohammad S, Raja R, Lal B, Gautam P, Bhattacharyya P, Kumar A, Tripathi R, Sangita M, Panda BB, Mohapatra SD, Das KM and Shukla AK (2013) Identification and Management of Nutrient Disorders and Diseases in Rice: A Visual Diagnostic Tool. Central Rice Research Institute, Cuttack, India.
Nieves-Cordones M, Ródenas R, Lara A, Martínez V and Rubio F (2019) The combination of K+ deficiency with other environmental stresses: what is the outcome?. Physiol. Plant. 165: 264-276.

Okuda A, Hori S and Ida S (1961) Boron nutrition in higher plants. I. A method of growing boron deficient plants. Journal of the Science of Soil and Manure, Japan 32:153-157.

Parkinson R (2013) System Based Integrated Nutrient Management. Soil Use Management 29 (4): 608.

Quijano-Guerta C, Kirk GJD, Portugal AM, Bartolome VI and McLaren GC (2002) Tolerance of rice germplasm to Zinc deficiency. Field Crop Res. 76:123-130

Rabeya K, Sahu SK and Mitra GN (1997) Yield maximization of rice through integrated Nutrient Management on Aeric Ustochrept. Journal of the Indian Society of Soil Science 45(2): 396-397.

Radha Madhav M, Ravikumar A and Venkateswarlu B (1996) Effect of different sources of nitrogen on growth, yield and nutrient uptake of rice. The Andhra Agricutltural Journal 43:119-122.

Rietra RPJJ, Heinen M, Dimkpa C and Bindraban PS (2015) Effects of nutrient antagonism and synergism on fertilizer use efficiency. VFRC Report 2015/5. Virtual Fertilizer Research Center, Washington, D.C. $42 \mathrm{pp}$

Roy AC and De Datta SK (1985) Phosphate sorption isotherms for evaluating phosphorus requirement of wetland rice soils. Plant Soil 86:185-196

RX Green Technology (2020) Nutrient antagonism. https://www.rxgreentechnologies.com/rxgt_papers/ nutrient-antagonism/

Sanyal SK and De Datta SK (1991) Chemistry of phosphorus transformations in soil. Advances in Soil Science 16:1-120

Selvi S and Ramaswami PP(1995) Residual effects of Integrated Nutrient Management in Rice-Rice-Pulse cropping sequence. Madras Agricultural Journal 82(1): 26-28.

Singh Y and Meelum OP (1995) Integrated nutrient management in rice. Progressive Farming, May: 12, 13 and 27.

Snyder GH and Jones DB (1988) Prediction of ironrelated rice seedling chlorosis on everglades Histosols. Soil Science Society of America Journal 52:1043-1046

Tahir RM, Noor-us-Sabah AM, Sarwar G, Rasool I and Noorka IR (2019) Smart Nutrition Management of Rice Crop under Climate Change Environment. Protecting Rice Grains in the Post-Genomic Era. IntechOpen Limited, UK.pp.1-11.

Udayasoorian C and Paramasivam P (1991) Changes in available NPK status after eight years of continuous manuring and fertilization in Rice-Rice Cropping 
Agrica

Vol. 9, June 2020 Page No. 53-62

system. Madras Agricultural Journal 78: 204-206.

Udayasoorian C, Sreeramulu US and Paramasivam P

(1989) Effect of continuous manuring and fertilization on the fractions of soil N. Madras Agricultural Journal 76(5): 257-261.
Wang Y and Wu WH (2013) Potassium transport and signaling in higher plants. Annu. Rev. Plant Biol. 64: 451-476.

Yoshida S (1981) Fundamentals of rice crops science. International Rice Research Institute, Los Baños. 